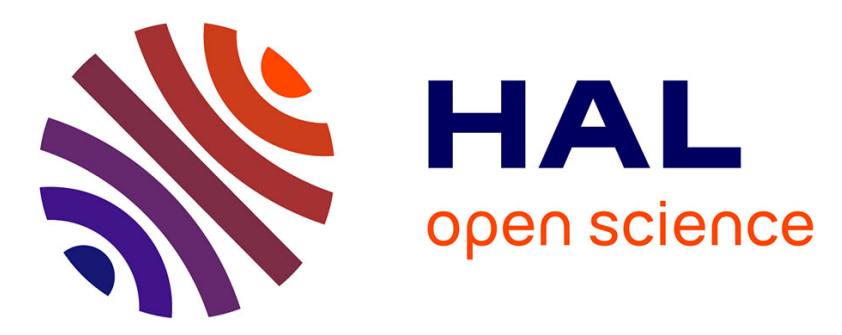

\title{
Natural recolonization of the Seine River by Atlantic salmon (Salmo salar) of multiple origins
}

C. Perrier, G. Evanno, J. Belliard, R. Guyomard, Jean-Luc J.-L. Baglinière

\section{To cite this version:}

C. Perrier, G. Evanno, J. Belliard, R. Guyomard, Jean-Luc J.-L. Baglinière. Natural recolonization of the Seine River by Atlantic salmon (Salmo salar) of multiple origins. Canadian Journal of Fisheries and Aquatic Sciences, 2010, 67 (1), p. 1 - p. 4. 10.1139/F09-190 . hal-00584140

\section{HAL Id: hal-00584140 \\ https://hal.science/hal-00584140}

Submitted on 7 Apr 2011

HAL is a multi-disciplinary open access archive for the deposit and dissemination of scientific research documents, whether they are published or not. The documents may come from teaching and research institutions in France or abroad, or from public or private research centers.
L'archive ouverte pluridisciplinaire HAL, est destinée au dépôt et à la diffusion de documents scientifiques de niveau recherche, publiés ou non, émanant des établissements d'enseignement et de recherche français ou étrangers, des laboratoires publics ou privés. 


\title{
Natural recolonization of the Seine River by Atlantic salmon (Salmo salar) of multiple origins
}

\author{
Charles Perrier, Guillaume Evanno, Jérôme Belliard, René Guyomard, and \\ Jean-Luc Baglinière
}

\begin{abstract}
The restoration of previously extinct salmon populations is usually achieved with stocking programmes, but natural recolonization can also occur through the straying of individuals from nearby populations. Here we investigated the origin of Atlantic salmon (Salmo salar) that recently recolonized the Seine River (France). The degradation of this river had led to the extinction of the population, but since the 1990s, the water quality has greatly improved. Although no stocking was performed, 162 individual salmon were recently observed by video-counting. Seven fish were sampled for morphological and genetic analyses. These individuals were genotyped at 17 microsatellites markers and their probable source populations were identified using baseline samples from regional and distant populations. Four of the sampled individuals were grilse and three were multi-sea-winter fish. Genetic analyses revealed that the fish partly originated from a nearby stock but also from distant populations, suggesting long-distance straying. This natural recolonization of a large river by strayers from several origins is discussed in terms of population sustainability and management.
\end{abstract}

Résumé : La restauration de populations antérieurement éradiquées de saumons se fait ordinairement par des programmes d'empoissonnement, mais il peut aussi exister une recolonisation naturelle par les individus errants des populations avoisinantes. Nous examinons ici l'origine des saumons atlantiques (Salmo salar) qui ont récemment recolonisé la Seine (France). La dégradation du fleuve avait entraîné l'extinction de la population, mais depuis les années 1990, la qualité de l'eau s'est grandement améliorée. Bien qu'aucun empoissonnement n'ait été effectué, 162 saumons individuels ont récemment été observés par comptage vidéo. Sept poissons ont été prélevés pour des analyses morphologiques et génétiques. Nous avons déterminé leur génotype à 17 marqueurs microsatellites et identifié leur population d'origine probable au moyen d'échantillons de référence provenant de populations régionales et éloignées. Quatre des individus prélevés étaient des madeleineaux et trois avait passé plusieurs hivers en mer. Les analyses génétiques montrent que les poissons proviennent en partie d'un stock voisin et en partie de populations lointaines, ce qui indique une errance sur de longues distances. Nous discutons de la recolonisation d'une grande rivière par des poissons errants d'origines diverses, en particulier de la durabilité et de la gestion de la population.

[Traduit par la Rédaction]

\section{Introduction}

Many Atlantic salmon (Salmo salar) populations are critically endangered, especially in large rivers, which are generally more impacted by human activities. In cases of extinct populations, recolonization can occur through the straying of individuals from nearby populations and (or) by the controversial use of stocking with hatchery-reared fishes (Myers et al. 2004). The results of stocking programmes are variable and have been amply documented (for a review, see Fraser
2008), whereas cases of natural recolonization by Atlantic salmon are rare and have been described only in small- or medium-sized river systems (Vasemägi et al. 2001; Saura et al. 2008). In brown trout (Salmo trutta), there are some examples of recolonization of large drainages by anadromous sea trout, for instance, the Rhine River (Schreiber and Diefenbach 2005). However, there is apparently no case of natural recolonization by Atlantic salmon of a large river system in which the population was previously extinct.

Received 28 July 2009. Accepted 13 November 2009. Published on the NRC Research Press Web site at cjfas.nrc.ca on 26 November 2009.

$\mathrm{J} 21323$

Paper handled by Associate Editor Michael Hansen.

C. Perrier, ${ }^{\mathbf{1}}$ G. Evanno, and J.-L. Baglinière. INRA, UMR 985 Ecology and Health of Ecosystems, 35042 Rennes, France; Agrocampus Ouest, 65 rue de Saint-Brieuc, 35042 Rennes, France.

J. Belliard. Cemagref, Hydrosystems and Bioprocesses Research Unit, Parc de Tourvoie, 92163 Antony, France.

R. Guyomard. INRA, UMR 1313 Animal Genetic and Integrativ Biology, Domaine de Vilvert, 78352 Jouy-en-Josas, France.

${ }^{1}$ Corresponding author (e-mail: charles.perrier@rennes.inra.fr). 
Fig. 1. (a) Map of the Seine drainage with locations of the observed and sampled salmon (Salmo salar) and (b) location of the Seine basin in France, as well as the five French baseline groups used for the genetic assignment tests.

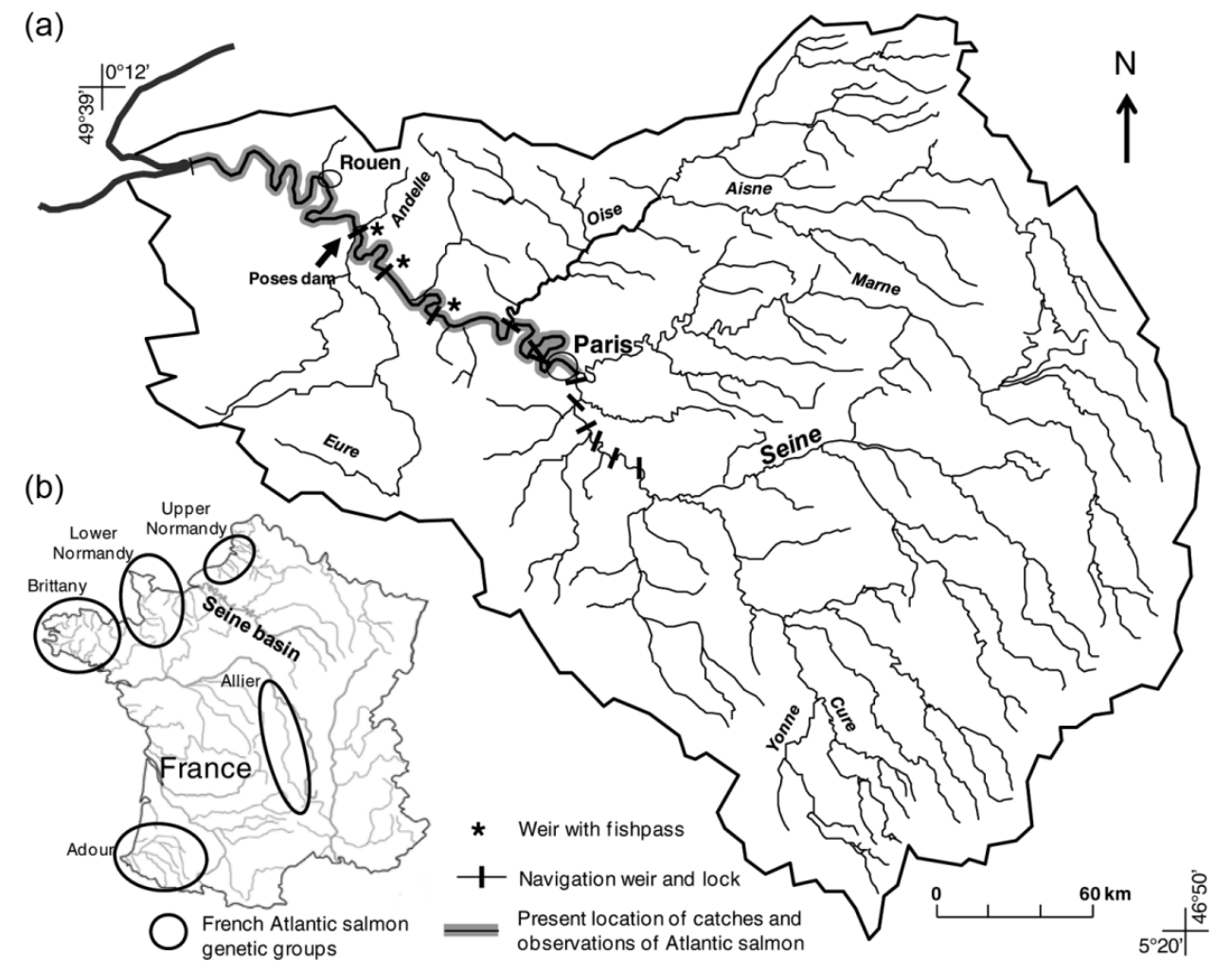

The Seine is a major French river with a basin area of $78.910 \mathrm{~km}^{2}$. A large Atlantic salmon population, including a large component of multi-sea-winter fish, dwelt in this river until the beginning of the 19th century (Lavollée 1902). This population progressively collapsed until the end of the 19th century due to obstruction to migration, canalization, and chronic degradation of water quality by industrial and domestic pollution (Lavollée 1902; Belliard et al. 2009). The only recorded stocking operations were performed during the 19th century and remained unsuccessful (Lavollée 1902; A. Richard, Délégation Interrégionale Nord-Ouest, ONEMA, 188 rue carlet, 27310 Bourg-Achard, France, unpublished data). The water quality clearly improved since the beginning of the 1990s, allowing the return of nine migratory species to the lower Seine (Belliard et al. 2009). One hundred and sixty-two adult Atlantic salmon were counted in 2008 in the video trap of the Poses Dam (A. Richard, unpublished data), located $160 \mathrm{~km}$ from the sea (Fig. 1a). Seven of them were adipose fin clipped (a common practice on stocked fishes), suggesting a low proportion of hatchery-reared fishes. Some adult salmon were also caught by angling or during scientific monitoring in lower parts of the river but also near Paris (and even in Paris; see Table 1).

The aim of the present study was to identify the probable source populations of the salmon recolonizing the Seine River using genetic assignment methods. We genotyped seven individuals caught in the Seine at 17 microsatellite markers and inferred their origin using six baseline groups: the five major French genetic units (Fig. 1b) and a group of foreign samples. Finally, we discuss the management op- tions that may allow the restoration of a self-sustaining salmon population in the Seine River.

\section{Materials and methods}

\section{Sampling}

Seven adult salmon caught by angling (salmon fishing is officially prohibited) or net fishing from 2001 to 2008 were sampled (Table 1). Total length and weight were measured and some scales were collected for age estimation and genetic analyses.

\section{Genetic analyses}

Genomic DNA was extracted from scale individual samples by heating in a $150 \mathrm{~mL}$ solution (proteinase $\mathrm{K}$, TE (Tris-EDTA) buffer, and 5\% Chelex) at $55{ }^{\circ} \mathrm{C}$ for $2 \mathrm{~h}$ and then at $100{ }^{\circ} \mathrm{C}$ for $10 \mathrm{~min}$. We used an economic method called "M13 method" for the fluorescent labelling of PCR fragments. DNA was amplified using 17 microsatellites (BHMS176; BHMS179A; BHMS184B; BHMS429; SSA85; SSA65; SSOSL85; SSA9; BHMS235; BHMS217; BHMS111; SSA197; SSA171; BHMS377; SSSP2216; SSA224; BHMS365; for more details on these markers, see Nikolic et al. 2009). Polymerase chain reaction (PCR) was carried out in a $10 \mathrm{~mL}$ reaction volume containing $1.5 \mathrm{mmol} \cdot \mathrm{L}^{-1} \mathrm{MgCl}_{2}, 200 \mathrm{mmol} \cdot \mathrm{L}^{-1} \mathrm{dNTPs}, 0.1 \mathrm{mmol} \cdot \mathrm{L}^{-1}$ forward primer, $0.15 \mathrm{mmol} \cdot \mathrm{L}^{-1}$ reverse primer, $0.15 \mathrm{mmol} \cdot \mathrm{L}^{-1} \mathrm{M} 13-\mathrm{Fluo}, 25-50 \mathrm{ng} \mathrm{DNA}$, and $0.5 \mathrm{U}$ Taq DNA polymerase. The amplification conditions were as follows: an initial denaturation for $5 \mathrm{~min}$ at $94{ }^{\circ} \mathrm{C}$, then $42-45$ cycles for $30 \mathrm{~s}$ at $94{ }^{\circ} \mathrm{C}, 30 \mathrm{~s}$ at annealing temperature, $30 \mathrm{~s}$ at $72{ }^{\circ} \mathrm{C}$, and a final synthesis for $30 \mathrm{~min}$ at $72{ }^{\circ} \mathrm{C}$. 


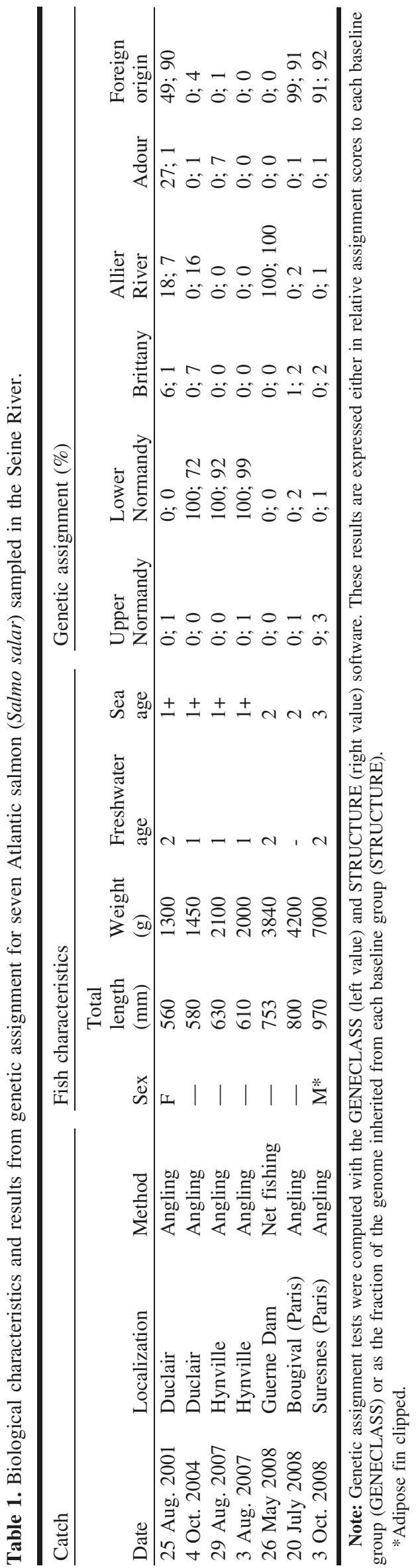

\section{Data analyses}

Genetic assignment of the seven Seine samples was performed using two Bayesian methods implemented in the software GENECLASS 2.0 (Piry et al. 2004) and STRUCTURE (Pritchard et al. 2000). For both analyses, we considered as baselines one group of foreign fishes from several Scottish, Danish, and Norwegian rivers (29 individuals) and the five major French genetic units (Fig. 1b): Upper Normandy, Lower Normandy, Brittany, Allier River, and Adour drainage (34 fish per unit). These five French groups were previously identified based on the analysis of 975 adult individuals originating from 34 French rivers (C. Perrier, J.-L. Baglinière, R. Guyomard, and G. Evanno, unpublished data). GENECLASS was used by assigning individuals to each of the six baseline groups using the Baudouin and Lebrun approach. STRUCTURE was run six times (mean values are given), with a burn-in period of 50000 steps followed by 500000 Markov chain Monte Carlo (MCMC) replicates, assuming six populations $(k=6)$, and an admixture model (i.e., allowing the genetic composition of individuals to be a mixture from the six different source populations).

\section{Results}

The adult salmon ranged in total length from 560 to $970 \mathrm{~mm}$ and weighed between 1300 and $7000 \mathrm{~g}$ (Table 1). Three fish were one-year-olds in freshwater and three were two-year-olds. Four salmon were grilse, two were two-seawinters, and the last one was three-sea-winters.

Genetic assignment showed that these fish had different origins (Table 1). Three grilse were assigned with GENECLASS software to Lower Normandy stock with $100 \%$ scores, and one multi-sea-winter fish was assigned to the Allier population with a score of $100 \%$. Two multi-sea-winter individuals were assigned to the foreign group with scores of $99 \%$ and $91 \%$, whereas the last grilse could not be unambiguously assigned to any stock. Assignment with STRUCTURE software gave similar results except that the last grilse was assigned to the foreign group with a score of $90 \%$.

\section{Discussion}

Our results suggest a high diversity in the origin of the fish recolonizing the Seine River. As no stocking operation has occurred in this river since the end of the 19th century (Lavollée 1902), the salmon recolonization can only be explained by natural straying. The sample size is small but sufficient to reveal that source populations are not only in nearby rivers (Lower Normandy region), but also in distant rivers (Allier River) or foreign stocks. The results were not congruent between the two assignment methods for one individual, meaning that this fish probably originated from an unsampled foreign population. Clearly, more samples from the Seine River and from foreign stocks would be needed to make a thorough analysis of the source populations and their relative contributions to this recolonization event. In particular, individuals assigned to the foreign stocks might also come from foreign hatcheries, sea farms, and (or) a foreign river where they had been stocked. Indeed, straying rates of hatchery-reared fishes are higher than those of wild individuals, and stocking is a widespread practice in the British 
Isles. In addition, one sampled individual and seven of the 162 fishes observed by video-counting were adipose fin clipped, suggesting that stocking in other rivers may have also played an indirect role in the recolonization of the Seine River. Stocking operations also occur in several French rivers, but only salmon of national origin are used (Vauclin 2005).

The fact that many individuals were observed by videocounting in 2008 and that some fish were assigned to the Lower Normandy stock may also reveal the presence of a small local population actually in establishment in a tributary localized in the lower basin. Indeed, as salmon learn the location of their home river when moving to sea, most of the individuals born in the Seine River will come back to their natal river to spawn (Jonsson et al. 1990).

The multiple origins that we observed could be a key factor for successful natural recolonization as they should result in higher genetic diversity within the settling population compared with a single-origin population. This higher genetic diversity should buffer the impact of losses of genetic variability linked to the low number of migrants during the early phases of recolonization. Alternatively, the fact that nearby Normandy populations could provide a large proportion of the founders may also facilitate the recolonization due to a better adaptation of the settlers to local environmental conditions (Dionne et al. 2008). This high overall evolutionary potential, in turn, would increase the probability of the new population reaching a self-sustainable stage.

The recolonization of the Atlantic salmon could be related to a general improvement of water quality in the estuary and lower parts of the river. More specifically, improving water quality resulted in recovering a good dissolved oxygen concentration (Belliard et al. 2009) and low ammonium concentrations. During the 19th century, known spawning grounds were restricted to some tributaries of the estuarine part of the Seine River and of the upper basin (Lavollée 1902). Currently, no spawning site was detected in the Seine drainage, but it seems that given the numerous obstacles to fish migration, only the tributaries located downstream could be used as spawning areas (e.g., the Andelle River).

Finally, fishpass management and water and habitat quality improvement seem the priorities to address to facilitate the sustainable natural recolonization of the Seine River by Atlantic salmon. More generally, this case study suggests that stocking may be superfluous for restoring previously extinct salmon populations in large river systems.

\section{Acknowledgments}

We thank A. Richard, P. Provost, F. Fournel, G. Euzenat, J.-P. Porcher (ONEMA, France), M. Ollitraut, N. Jeannot (INRA Rennes, France), la Maison de la Pêche et de la Nature (Levallois, Paris), MIGADO, and the CNSS for their help in collecting scale samples. We are also grateful to M. Hansen and two anonymous referees for their helpful comments that significantly improved the manuscript. N. Ni- kolic's help with the genetic analyses was greatly appreciated. Samples were genotyped at the Toulouse Genopole Platform (http://www.genotoul.fr/). This study was supported by grants from INRA and Région Basse-Normandie to C.P.

\section{References}

Belliard, J., Marchal, J., Ditche, J.-M., Tales, E., Sabatié, R., and Baglinière, J.-L. 2009. Return of adult anadromous allis shad (Alosa alosa L.) in the river Seine, France: a sign of river recovery? River Res. Appl. 25(6): 788-794. doi:10.1002/rra.1221.

Dionne, M., Caron, F., Dodson, J.J., and Bernatchez, L. 2008. Landscape genetics and hierarchical genetic structure in Atlantic salmon: the interaction of gene flow and local adaptation. Mol. Ecol. 17(10): 2382-2396. doi:10.1111/j.1365-294X.2008.03771. x. PMID:18430145.

Fraser, D.J. 2008. How well can captive breeding programs conserve biodiversity? A review of salmonids. Evol. Appl. 1(4): $535-586$.

Jonsson, B., Jonsson, N., and Hansen, L.P. 1990. Does juvenile experience affect migration and spawning of adult Atlantic salmon? Behav. Ecol. Sociobiol. 26(4): 225-230. doi:10.1007/ BF00178315.

Lavollée, M.G. 1902. Le saumon en Seine. Bulletin de la Société Centrale d'Aquiculture et de Pêche, 14: 221-234.

Myers, R.A., Levin, S.A., Lande, R., James, F.C., Murdoch, W.W., and Paine, R.T. 2004. Ecology. Hatcheries and endangered salmon. Science (Washington, D.C.), 303(5666): 1980. doi:10. 1126/science.1095410. PMID:15044790.

Nikolic, N., Feve, K., Chevalet, C., Hoyheim, B., and Riquet, J. 2009. A set of 37 microsatellite DNA markers for genetic diversity and structure analysis of Atlantic salmon Salmo salar populations. J. Fish Biol. 74: 458-466.

Piry, S., Alapetite, A., Cornuet, J.M., Paetkau, D., Baudouin, L., and Estoup, A. 2004. GENECLASS2: a software for genetic assignment and first-generation migrant detection. J. Hered. 95(6): 536-539. doi:10.1093/jhered/esh074. PMID:15475402.

Pritchard, J.K., Stephens, M., and Donnelly, P. 2000. Inference of population structure using multilocus genotype data. Genetics, 155(2): 945-959. PMID:10835412.

Saura, M., Caballero, P., and Moran, P. 2008. Are there Atlantic salmon in the River Tambre? J. Fish Biol. 72(5): 1223-1229. doi:10.1111/j.1095-8649.2007.01782.x.

Schreiber, A., and Diefenbach, G. 2005. Population genetics of the European trout (Salmo trutta L.) migration system in the river Rhine: recolonisation by sea trout. Ecol. Freshwat. Fish, 14(1): 1-13. doi:10.1111/j.1600-0633.2004.00072.x.

Vasemägi, A., Gross, R., Paaver, T., Kangur, M., Nilsson, J., and Eriksson, L.O. 2001. Identification of the origin of an Atlantic salmon (Salmo salar L.) population in a recently recolonized river in the Baltic Sea. Mol. Ecol. 10(12): 2877-2882. doi:10. 1046/j.1365-294X.2001.t01-1-01407.x. PMID:11903899.

Vauclin, V. 2005. National fisheries and status of salmon stocks in France. National report for 2004. ICES Working Group on North Atlantic Salmon Working Paper No. 8. International Council for the Exploration of the Sea, Copenhagen, Denmark. 